\title{
Optimasi Pati-Alginat sebagai Bahan Pengkapsul Bakteri Probiotik terhadap Karakteristik Beads
}

\section{Optimation Starch-alginate for Probiotic Bacteria Encapsulant Based on Beads Characteristic}

Miskiyah*, Widaningrum, Juniawati

Balai Besar Penelitian dan Pengembangan Pascapanen Pertanian, Kementerian Pertanian Republik Indonesia, Bogor

Korespondensi dengan penulis (miski_pascapanen2005@yahoo.co.id)

Artikel ini dikirim pada tanggal 27 Maret 2019 dan dinyatakan diterima tanggal 11 Februari 2020. Artikel ini juga dipublikasi secara online melalui https://ejournal2.undip.ac.id/index.php/jatp. Hak cipta dilindungi undang-undang. Dilarang diperbanyak untuk tujuan komersial.

Diproduksi oleh Indonesian Food Technologists® @2020

\begin{abstract}
Abstrak
Enkapsulasi merupakan proses pembungkusan (coating) suatu bahan inti dengan menggunakan bahan pengkapsul tertentu. Pemanfaatan maltodekstrin, pati sagu, dan maizena sebagai bahan pengkapsul probiotik belum banyak dikembangkan sehingga dapat dijadikan kandidat bahan pengkapsul baru. Tujuan penelitian ini untuk menentukan konsentrasi pati-alginat terbaik yang dapat digunakan untuk enkapsulasi probiotik. Rancangan percobaan yang digunakan adalah rancangan faktorial menggunakan 2 faktor, yaitu jenis bahan pengkapsul dan perbandingan konsentrasi bahan pengkapsul. Faktor jenis bahan pengkasul terdiri dari 3 taraf yaitu maltodekstrinalginat, pati sagu-alginat, dan maizena-alginat, sedangkan faktor konsentrasi bahan pengkapsul terdiri dari 3 taraf yaitu 1:1; 1:2; dan 1:3 (b/b). Pembuatan beads dilakukan dengan teknik ekstrusi (prinsip gelasi ionik) dengan agen crosslinker $\mathrm{CaCl}_{2}$. Hasil penelitian menunjukkan bahwa perbandingan pati-alginat secara bervariasi menghasilkan karakteristik beads dari segi rendemen, diameter beads, dan bentuk beads yang spesifik. Kesimpulannya, bahan pengkapsul probiotik yang terbaik yaitu perbandingan pati:alginat sebesar 1:3.
\end{abstract}

Kata kunci : pati, alginat, bahan pengkapsul, karakteristik, beads

\begin{abstract}
Encapsulation was known as process of coating a core material using specific materials. The use of maltodextrin, sago starch, and corn starch as a probiotic material for encapsulation has not been widely developed as new material. The aim of the study was to determine the best ratio of starch-alginate concentrations. The experimental design was factorial design using 2 factors, i.e. type of material and the concentration. The type of material for encapsulation consisted of maltodextrin-alginate, sago-alginate starch, and cornstarch-alginate, while the concentration was 1:1, 1:2, and 1:3 (w/W). The beads were produced by extrusion methods (ionic gelation principle) with $\mathrm{CaCl}$ as crosslinker. The results showed that the varioys types of materials and concentration provided specific beads characteristic, i.e. yield, beads diameter, and beads shape. As conclusion, the optimum ratio of starchalginate as probiotic encapsulating could be determined at a ratio of 1:3.
\end{abstract}

Keywords: starch, alginate, material for encapsulation, characteristics, beads

\begin{abstract}
Pendahuluan
Enkapsulasi merupakan proses pembungkusan (coating) suatu bahan inti dengan menggunakan bahan pengkapsul tertentu. Salah satu teknologi modern yang tepat untuk mempertahankan probiotik adalah dengan mikroenkapsulasi (Zanjani et al., 2014). Enkapsulasi dapat mempertahankan probiotik selama proses pengolahan dan penyimpanan pada kondisi yang ekstrim (Chavarri et al., 2012) dan pH asam dalam saluran pencernaan (Burgain, 2011). Genus yang paling banyak dikembangkan adalah golongan Lactobacillus dan Bifidobacterium (Homayouni et al., 2008). Terdapat beberapa metode enkapsulasi, salah satunya adalah dengan Teknik ekstrusi (droplet method) yang merupakan salah satu teknik tergolong sederhana karena relatif mudah dan tidak membutuhkan biaya yang mahal (Widaningrum et al., 2018). Teknik ekstrusi juga dapat mempertahankan viabilitas bakteri Lactobacillus casei karena tidak menggunakan suhu tinggi (Rokka dan Pirjo, 2010).
\end{abstract}

Penggunaan pati alami sebagai enkapsulan sintetis diketahui mempunyai beberapa keunggulan diantaranya mudah terdegradasi, murah dan mudah dimodifikasi sifat fisik atau kimia (Lu et al., 2009). Eksplorasi pemanfaatan pati sebagai bahan pengkapsul probiotik sudah banyak dikembangkan, namun penggunaan sumber pati sagu dan maizena dapat dijadikan kandidat bahan pengkapsul baru yang lebih mudah diperoleh di pasaran. Kombinasinya dengan alginat diharapkan dapat menghasilkan beads yang mempunyai karakteristik dan mampu melindungi probiotik target. Pati jagung dengan kadar amilosa tinggi (high amylose corn starch) dapat meningkat efektifitasnya sebagai bahan pengkapsul (Dimantov et al., 2003). Pati sagu yang merupakan resistant starch diharapkan memiliki karakteristik bahan pengkapsul yang lebih baik karena dapat melindungi probiotik selama berada dalam saluran pencernaan (Thomson, 2000).

Alginat merupakan polimer karbohidrat dan heteropolisakarida alami yang telah banyak digunakan 
dalam enkapsulasi (Homayouni et al., 2008, Mokarram et al., 2009). Penelitian yang dilakukan oleh Sultana et al., (2000) menunjukkan bahwa penggunaan pati jagung sebagai sumber pati untuk enkapsulasi belum menunjukkan ukuran beads yang sama, sehingga memerlukan perbaikan lebih lanjut. Tujuan penelitian ini dilakukan untuk menentukan perbandingan konsentrasi pati-alginat yang terbaik sehingga selanjutnya dapat digunakan untuk enkapsulasi probiotik. Manfaat yang dapat diambil dari penelitian ini adalah mendapatkan informasi tentang pengaruh bahan pengkapsul yakni pati-alginat terhadap karakteristik beads.

\section{Materi dan Metode \\ Materi}

Penelitian ini dilaksanakan di Laboratorium Mikrobiologi Balai Besar Penelitian dan Pengembangan Pascapanen Pertanian Bogor. Bahan-bahan yang digunakan dalam penelitian adalah natrium alginat, skim (Sunlac®), maltodekstrin, pati sagu komersial, maizena komersial. Bahan kimia yang digunakan adalah air destilata (aquadest), $\mathrm{CaCl}_{2}, \mathrm{NaCl}$, PBS (Phosfat Buffer Saline) (Merck, Jerman), $\mathrm{NaOH}$.

Peralatan yang digunakan selama proses penelitian meliputi inkubator seri 403-1 (Lab-line, US), autoclave HVE-50 (Hirayama, Jepang), oven (Memmert, Jerman), refrigerator, vortex, shaker, syringe, stirer, mikropipet, pipet tip, ose, timbangan analitik, $\mathrm{pH}$ meter HI-2211 (Hanna, Singapore), jangka sorong, cawan petri, bunsen, dan peralatan gelas.

\section{Proses Pembuatan Beads}

Proses pembuatan beads mengacu pada penelitian yang dilakukan oleh Mandal et al. (2016). Beads dibuat dengan komposisi sesuai perlakuan perbandingan sumber pati dengan alginat. Masingmasing perlakuan dibuat sebanyak $20 \mathrm{ml}$ suspensi bahan pengkapsul yang terdiri atas pati-alginat dengan perbandingan 1:1 (2:2\%), 1:2 (1,3:2,7\%), dan 1:3 (1:3\%) (b/b) dari masing-masing jenis pati perlakuan dengan jumlah total padatan sebanyak $4 \%$. Penggunaan total padatan sebesar $4 \%$ mengacu pada penelitian Mandal et al. (2006). Sebagai kontrol, digunakan bahan pengkapsul susu skim-alginat dengan komposisi 1:2 (1,3\% skim : 2,7\% alginat). Komposisi masing-masing perlakuan tersebut dilarutkan dengan akuades hingga $20 \mathrm{ml}$. Semua suspensi bahan pengkapsul selanjutnya disterilisasi terlebih dahulu pada suhu $121^{\circ} \mathrm{C}$ selama 15 menit. Setelah dingin, suspensi dimasukkan ke dalam syringe lalu diteteskan ke dalam $\mathrm{CaCl}_{2} 0,1 \mathrm{M}$ hingga terbentuk beads (Krasaekoopt et al., 2003). Beads yang diperoleh kemudian disaring dan dibilas dengan $\mathrm{NaCl}$ $0,85 \%$ steril untuk dilakukan analisis.

\section{Penentuan Perbandingan Pati-Alginat Optimum}

Komposisi optimum pati-alginat terbaik ditentukan berdasarkan nilai rendemen, bentuk beads, dan diameter beads yang dihasilkan dari tiap perlakuan. Diameter beads diukur menggunakan jangka sorong pada beads basah yang dihasilkan. Pada penelitian ini, pengamatan bentuk beads dilakukan secara visual.
Penghitungan Rendemen Beads

Rendemen beads basah (\%) dihitung dengan menimbang massa beads basah (g) dibagi dengan massa suspensi bahan pengkapsul (g) dan dikalikan dengan 100\% (El Say, 2016).

\section{Analisis Data}

Rancangan percobaan yang digunakan dalam penelitian ini adalah rancangan faktorial menggunakan 2 faktor, yaitu jenis bahan pengkapsul dan perbandingan konsentrasi bahan pengkapsul. Faktor jenis bahan pengkasul terdiri dari 3 taraf yaitu maltodekstrin-alginat, pati sagu-alginat, dan maizena-alginat, sedangkan faktor perbandingan konsentrasi bahan pengkapsul terdiri dari 3 taraf yaitu $1: 1,1: 2$, dan $1: 3(\mathrm{~b} / \mathrm{b})$. Analisis statistik dilakukan untuk menentukan perbandingan komposisi pati-alginat yang paling optimum. Data diolah menggunakan analysis of variance (ANOVA) dengan uji lanjut Duncan pada taraf signifikansi $95 \%$.

\section{Hasil dan Pembahasan}

Rendemen Beads Pati-Alginat

Jenis pati yang digunakan dalam penelitian ini adalah maltodekstrin, pati sagu, dan maizena. Ketiga jenis pati ini berfungsi sebagai bahan pengkapsul yang selanjutnya dicampur dengan alginat. Penambahan bahan pengisi diharapkan mampu mempertahankan viabilitas bakteri probiotik selama proses pengeringan sehingga dapat diperoleh starter kering probiotik dengan viabilitas yang tinggi.

Parameter penentuan perbandingan pati-alginat optimum dinilai berdasarkan rendemen, bentuk dan ukuran beads yang dihasilkan. Rendemen beads dari masing-masing bahan pengkapsul dihitung berdasarkan perbandingan massa beads dengan massa suspensi. Pengaruh perbandingan pati-alginat terhadap rendemen beads terlihat pada Figur 1.

Berdasarkan hasil analisis statistik menunjukkan bahwa perbandingan pati-alginat berpengaruh nyata $(p<0,05)$ terhadap rendemen beads yang dihasilkan. Pada perbandingan 1:1 maltodekstrin-alginat memiliki rendemen $54,37 \%$, pati sagu-alginat $57,16 \%$, dan maizena-alginat 54,92\%. Pada perbandingan 1:2 maltodekstrin-alginat memiliki rendemen $55,30 \%$, pati sagu-alginat $58,56 \%$, dan maizena-alginat $58,14 \%$, sedangkan pada perbandingan 1:3 maltodekstrin-alginat memiliki rendemen $61,48 \%$ pati sagu-alginat $59,16 \%$, dan maizena-alginat $63,67 \%$. Skim-alginat (sebagai kontrol) dengan perbandingan 1:2, memiliki rendemen terendah yaitu $49,61 \%$.

Terlihat bahwa secara umum pada semua jenis bahan pengkapsul, semakin tinggi konsentrasi alginat yang digunakan maka semakin tinggi rendemen yang dihasilkan. Hal ini dikarenakan dengan semakin tinggi konsentrasi alginat maka semakin banyak anion karboksilat alginat yang bereaksi dengan ion $\mathrm{Ca}^{2+}$ membentuk jaringan tiga dimensi, sehingga semakin banyak matriks yang terbentuk (Nussinovitch, 2010). Sebaliknya semakin tinggi konsentrasi pati yang digunakan dapat menghalangi pembentukan matriks dan menyebabkan penurunan rendemen beads. Selain 
itu penambahan konsentrasi pati hingga $2 \%$ menyebabkan pati sulit larut dengan alginat dan mengendap setelah proses sterilisasi.

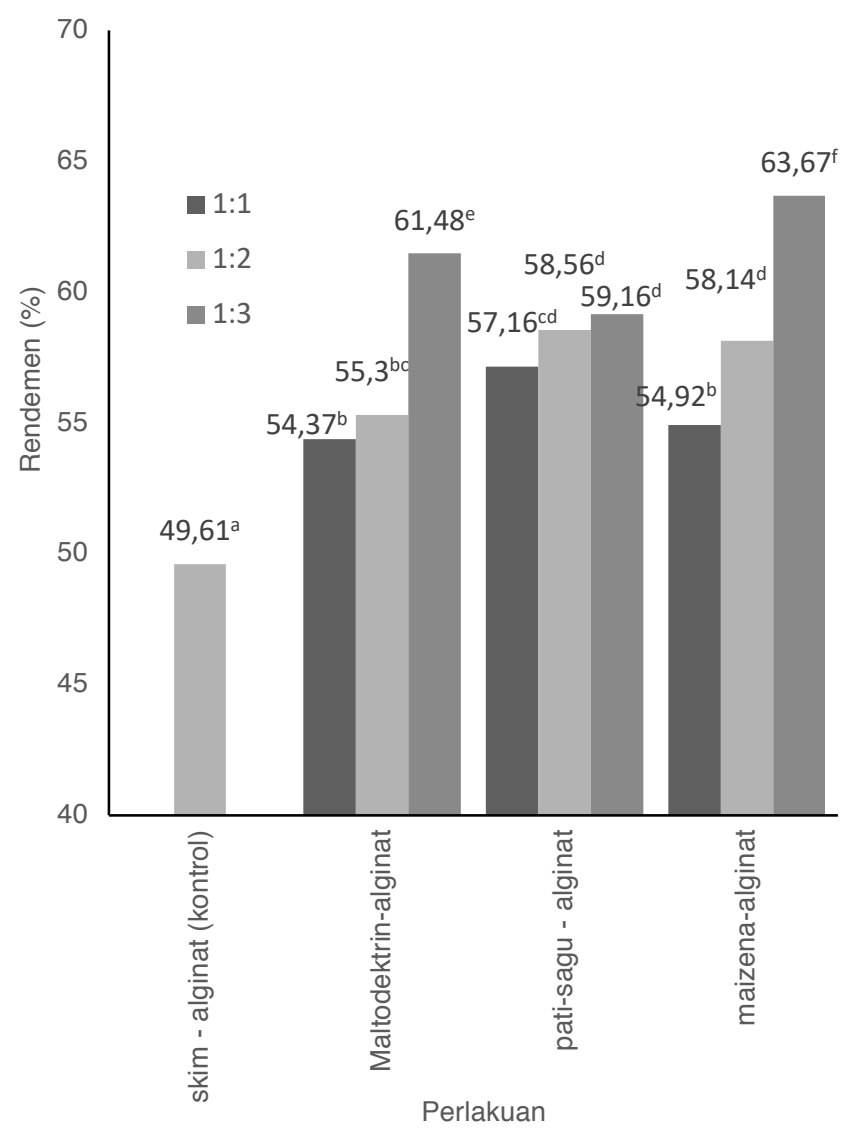

Figur 1. Persentase randemen yang dihasilkan dari perbandingan pati-alginat terhadap rendemen beads. Keterangan: Grafik dengan huruf yang berbeda menunjukkan nilai yang berbeda nyata $(p<0,05)$

Figur 1 juga menunjukkan bahwa perlakuan perbandingan bahan pengkapsul (1:2) jika dibandingkan dengan kontrol (skim alginat 1:2) secara statitik menunjukkan perbedaan yang nyata terhadap rendemen beads, dimana perlakuan bahan pengkapsul pati sagu: alginat $(1: 2)$ rendemennya paling tinggi dibandingkan dengan perlakuan lainnya. Enkapsulan dari karbohidrat (pati dan turunannya) mempunyai viskositas rendah pada kandungan padatan yang tinggi, serta kelarutan yang baik sehingga cocok digunakan sebagai bahan pengkapsul (Madene et al., 2006). Kombinasi pati sagu sebagai bahan pengkapsul dengan alginat berpotensi sebagai pengganti skim sebagai bahan enkapsulan.

\section{Diameter Beads}

Castilla et al. (2010) mengatakan perbandingan biopolimer yang digunakan dalam proses enkapsulasi dapat mempengaruhi diameter dan bentuk beads yang dihasilkan. Berdasarkan hasil analisis, perbandingan bahan pengkapsul berpengaruh nyata $(p<0,05)$ terhadap diameter beads namun tidak mempengaruhi bentuk beads yang dihasilkan.
Tabel 1 Pengaruh perbandingan pati-alginat terhadap diameter dan bentuk beads

\begin{tabular}{lccc}
$\begin{array}{l}\text { Jenis bahan } \\
\text { pengkapsul }\end{array}$ & $\begin{array}{c}\text { Perbandingan } \\
\text { bahan } \\
\text { pengkapsul }\end{array}$ & $\begin{array}{c}\text { Diameter } \\
\text { beads }(\mathrm{mm})^{\star}\end{array}$ & $\begin{array}{c}\text { Bentuk } \\
\text { beads }\end{array}$ \\
\hline $\begin{array}{l}\text { Skim - alginat } \\
\text { (kontrol) }\end{array}$ & $1: 2$ & $2,15 \pm 0,11^{\mathrm{b}}$ & Bulat \\
Maltodekstrin- & $1: 1$ & $2,00 \pm 1,12^{\mathrm{a}}$ & Bulat \\
alginat & $1: 2$ & $2,38 \pm 0,12^{\mathrm{c}}$ & Bulat \\
& $1: 3$ & $2,59 \pm 0,10^{\mathrm{d}}$ & Bulat \\
Pati sagu - & $1: 1$ & $2,10 \pm 0,13^{\mathrm{a}}$ & Bulat-oval \\
Alginat & $1: 2$ & $2,48 \pm 0,06^{\mathrm{cd}}$ & Bulat \\
& $1: 3$ & $2,72 \pm 0,17^{\mathrm{e}}$ & Bulat \\
Maizena - & $1: 1$ & $2,55 \pm 0,15^{\mathrm{d}}$ & Bulat \\
Alginat & $1: 2$ & $2,84 \pm 0,14^{\mathrm{f}}$ & Bulat \\
& $1: 3$ & $3,00 \pm 0,-.13^{\mathrm{g}}$ & Bulat \\
\hline
\end{tabular}

Keterangan: Diameter beads merupakan nilai rata-rata \pm standar deviasi dari pengukuran 10 beads. Nilai diameter dengan huruf yang berbeda menunjukkan nilai yang berbeda nyata $(p<0,05)$ berdasarkan uji lanjut Duncan.

Tabel 1 menunjukkan bahwa semakin tinggi konsentrasi alginat yang digunakan, semakin besar diameter beads yang dihasilkan. Hal ini dikarenakan peningkatan konsentrasi alginat dapat meningkatkan interaksi anion karboksilat alginat dengan kation $\mathrm{Ca}^{2+}$ dari $\mathrm{CaCl}_{2}$, sehingga matriks dan diameter beads yang terbentuk lebih besar. Berdasarkan hasil yang diperoleh, rendemen berkorelasi positif dengan diameter beads yang dihasilkan. Semakin tinggi konsentrasi alginat yang digunakan, semakin tinggi rendemen dan diameter beads yang diperoleh. Peningkatan rendemen diduga karena efisiensi proses enkapsulasi. Hal ini dikarenakan nilai efisiensi enkapsulasi diperoleh dari perbandingan total probiotik pada beads basah dengan total probiotik pada suspensi bahan pengkapsul. Semakin besar massa dan rendemen beads yang dihasilkan diharapkan mampu meningkatkan nilai efisiensi enkapsulasi.

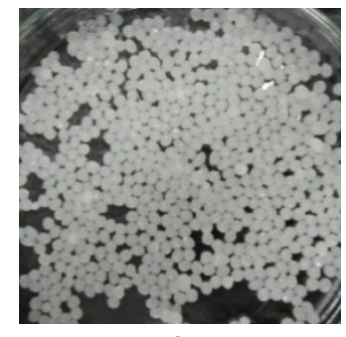

a

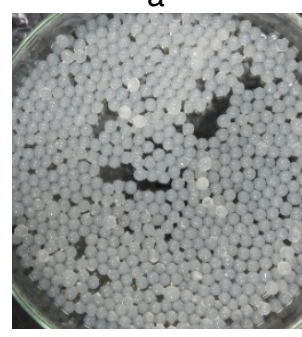

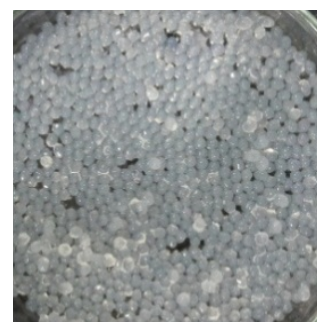

b

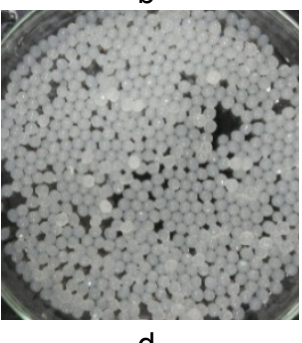

Figur 2. Penampakan beads dari bahan pengkapsul (a) skimalginat, (b) maltodekstrin-alginat, (c) pati sagu-alginat, dan (d) maizena-alginat pada perbandingan 1:3.

Enkapsulasi alginat, pati dan kitosan yang dilakukan oleh Zanjani et al. (2014) menggunakan teknik emulsi diketahui menghasilkan ukuran diameter beads yang lebih kecil dan berukuran mikron. Ukuran beads 
meningkat dengan penambahan kitosan. Namun, hasil penelitian lain menyebutkan bahwa ukuran beads tidak menunjukkan peningkatan yang signifikan terhadap ketahanan probiotik di saluran pencernaan (Fahimdanesh et al., 2012). Hasil penelitian ini sejalan dengan penelitian yang dilakukan oleh Sultana et al (2000) dan Castilla et al. (2010), dimana efisiensi enkapsulasi sel meningkat seiring dengan meningkatnya rendemen beads. Lee dan Heo (2000) juga menyatakan bahwa laju kematian Bifidobacterium longum terenkapsulasi alginat dapat menurun seiring peningkatan ukuran kapsul dan konsentrasi alginat.

\section{Bentuk Beads}

Berdasarkan hasil pengamatan maka perbandingan pati-alginat optimum yang berpotensi untuk dapat digunakan sebagai bahan pengkapsul probiotik, adalah pada perbandingan pati-alginat 1:3. Penampakan beads dari masing-masing bahan pengkapsul pada perbandingan 1:3 terlihat pada Figur 2. Perbedaan keempat beads adalah terdapat pada diameter dan warna beads, sedangkan bentuk beads relatif sama, yaitu bulat. Hasil penelitian yang dilakukan oleh Fujiwara et al. (2013) menghasilkan mikropartikel yang sedikit oval. Pada perbandingan 1:3, diameter beads terkecil diperoleh dari bahan pengkapsul skimalginat (kontrol), sedangkan diameter beads terbesar diperoleh dari bahan pengkapsul maizena-alginat. Sementara dari segi warna, beads dari bahan pengkapsul skim-alginat dan maizena-alginat terlihat lebih putih dibanding beads dari bahan pengkapsul maltodekstrin-alginat dan pati sagu-alginat. Warna putih pada beads skim-alginat dan maizena-alginat disebabkan oleh bubuk skim dan tepung maizena yang berwarna putih, sedangkan bubuk maltodekstrin dan pati sagu berwarna putih kekuningan dan putih kecoklatan. Penggunaan pati dalam enkapsulasi memungkinkan partikel yang dihasilkan mempunyai stabilitas yang lebih baik selama proses pengeringan, demikian juga reaksi intermolekular serta kompatibilitas molekular yang baik terjadi antara polimer pati dan alginat (Wang et al., 2010).

\section{Kesimpulan}

Perbandingan pati-alginat optimum yang berpotensi untuk dapat digunakan sebagai bahan pengkapsul probiotik adalah pada perbandingan patialginat $1: 3$ (1\% pati : $3 \%$ alginat), dari segi rendemen, diameter beads, dan bentuk beads.

\section{Ucapan Terimakasih}

Ucapan terimakasih ditujukan kepada BB Litbang Pascapanen yang telah mendanai kegiatan penelitian ini dan Husnal Chairi Hidayah mahasiswa Departemen IImu dan Teknologi Pangan Institut Pertanian Bogor yang ikut membantu dalam penyelesaian kegiatan penelitian.

\section{Daftar Pustaka}

Burgain, C., Gaiani, C., Linder, M., Scher, J. 2011. Encapsulation of probiotic living cells: from laboratory scale to industrial applications. Journal of Food Engineering 104:467-483. DOI:10.1016/j.jfoodeng.2010.12.031.

Castilla, O.S., Calleros, C.L., Galindo, H.S.G., Ramirez, J.A., Carter, E.J.V. 2010. Textural properties of alginate-pectin beads survivability of entrapped $L$. casei in simulated gastrointestinal condition and in yoghurt. Journal of Food Research International 43(1):111-117. 10.1016/j.foodres.2009.09.010.

Chavarri, M., Villaran, M.C. Maranon, I. 2012. Encapsulation technology to protect probiotic bacteria. Chapter 23: 501-540. Intech Open, UK. DOI: $10.5772 / 50046$.

Dimantov, A., Greenberg, M., Kesselman, E., Shimoni. 2003. Study of high amylase corn starch as food grade enteric coating in a microcapsule model systems. Innovative Food Science and Emerging Technologies 5:93-100. DOI:10.1016/j.ifset. 2003.11.003.

El-Say, K.M. 2016. Maximizing encapsulation efficiency and the bioavailability of controlled release cetirizine microspheres using Draper-Lin Small Composite Design. Drug Design, Development, and Therapy Journal (10):825-839. DOI:10.2147/ DDDT.S101900.

Fahimdanesh, M, Mahammadi, N, Ahari, H., Zanjani, M.S.K., Hargalani, F.Z., Berrouznasab, K. 2012. Effect of microencapsulation plus resistant starch on survival of Lactobacillus casei and Bifidobacterium bifidum in mayonaise sauce. African Journal of Microbiology Research 6:68536858. DOI 10.5897/AJMR 12.1240.

Fujiwara, S.M., Campos, R., Costa, C.K. Dias, J.F.G, Miguel, O.G., Miguel, M.D., Marques, F.A, Zanin, S.M.W. 2013. Production and characterization of alginate-starch-chitosan microparticles containing stigmasterol through the external ionic gelation technique. Brazillian Journal of Pharmaceutical Sciences 49:3: 537-546.

Homayouni, A., Azizi, A., Ehsani, M.R., Yarmand, M.S., Razavi, S.H. 2008. Effect of microencapsulation and resistant starch on the probiotic survival and sensory properties of synbiotic ice cream. Food Chemistry 111(1):50-55. DOI:10.1016/ j.foodchem.2008.03.036.

Krasaekoopt, W., Bhandari, B., Deeth, H. 2003. Evaluation of encapsulation techniques of probiotics for yoghurt. International Dairy Journal 13:3-13. DOI:10.1016/S0958-6946(02)00155-3.

Lee, K., Heo, T., 2000. Survival of Bifidobacterium longum immobilized in calcium alginate beads in simulated gastric juices and bile salt solution. Applied and Environmental Microbiology 66(2):869-873. PMCID: 91913.

Lu, D.R., Xiao, C.M., Xu, S.J. 2009. Strach-based completely biodegradable polimer materials. Express Polymer Letters 3(6):366-375. DOI: 10.3144/Expresspolymlett.2009.46.

Madene, A., Jacquot, M., Scher, J., Desobry, S. 2006. Flavour encapsulation and controlled release-a 
review. International Journal of Food Science and Technology 41:1-21.DOI:10.1155/1796.

Mandal, S., Puniya, A.K., Singh, K. 2006. Effect of alginate concentrations on microencapsulated Lactobacillus casei NCDC-298. International Dairy Journal 16:1190-1195. DOI:10.1016/ j.idairyj.2005.10.005.

Mokarram, R.R., Mortazavi, S.A., Najafi, M.B.H., Shahidi, F. 2009. The influence of multi stage alginate coating on survivability of potential probiotic bacteria in simulated gastric and intestinal juice. Food Research International 42:1040-1045. DOI:10.1016/j.foodres.2009. 04.023.

Nussinovitch, A. 2010. Bead Formation, Strengthening, Modification. In Nussinovitch, A. (Editor). Polymer macro- and micro- gel beads:fundamental and applications. New York (US): Springer Science. DOI 10.1007/978-1-4419-6618-6_2.

Rokka, S., Rantamaki, P. 2010. Protecting probiotic bacteria by microencapsulation: Challenges for industrial applications. European Food Research and Technology 231(1):1-12.

Sultana, K., Godward, G., Reynolds, N., Arumugaswamy, R., Peiris, P., Kailasapathy, K. 2000. Encapsulation of probiotics bacteria with alginate starch and evaluation of survival in simulated gastrointestinal conditions and in yoghurt. International Journal of Food Microbiology 62(1):47-55. PMID:11139021.
Thomson, D.B., 2000. Strategies of the manufacture od resistant starch. Trends in Food Science Technology 11:245-253. DOI:10.1016/s09242244(11)-00005-x.

Wang, Q., Hu, X., Du, Y., Kennedy, J. 2010. Alginate/starch blend fibers and their properties for drug controlled release. Carbohydrate Polymer 82(3):842-847. DOI: DOI: 10.1016/j.carbpol.2010.06.004.

Widaningrum, Miskiyah, Indrasti, Hidaya. 2018. Improvement of viability of Lactobacillus casei and Bifidobacterium longum with several encapsulating materials using extrusion method. Jurnal IImu Ternak dan Veteriner 23(4): 189-201. DOI 10.14334/jitv.v23i4.1547.

Zanjani, M.A.K., Tarzi, B.G., Sharifan, A. Mohamadi, N., 2014. Microencapsulation of probiotic by calcium alginate-gelatinized with chitosan coating and evaluation of survival in similated human gastrointestinal condition. Iranian Journal of Pharmaceutical Research,13 (3):843-852. PMID:25276184. 